\title{
Desenvolvimento
}

\section{numa economia mundial liberalizada e globalizante: um desafio impossível?}

\author{
IGNACY SACHS
}

\begin{abstract}
"Qual deverá ser o fim do homem e como ele deverá escolher seus meios? O racionalismo econômico, no senso estrito, não tem resposta a essas perguntas, pois implicam motivações e conceitos de valor de uma ordem moral e prática que vão além da exortação irresistível, conquanto vazia, de ser "econômico"'
\end{abstract}

Karl Polanyi, The economistic fallacy.

\begin{abstract}
"Mas onde encontrar o médico prudente que traçará as leis da higiene monetária e fornecerá os meios de evitar os acidentes?"

Honoré de Balzac, Code de gens honnêtes ou l'art de ne pas être dupe des fripons.
\end{abstract}

Entre a retórica e a realidade: um prólogo semântico

$\mathrm{P}$ ALAVRAS SÃo IMPORTANTES, principalmente quando polissêmicas. A comunicação torna-se por demais difícil, ou mesmo impossível, quando as pessoas usam o mesmo termo para denotar diferentes coisas sem explicitar seu significado real. Outras armadilhas semânticas com as quais se deve ter cuidado são a diplomacia por terminologia exposta por Gunnar Myrdal (1) e confundir a entoação de um hino com a resolução de problemas.

A palavra de ordem hoje é globalização. Sua popularidade deve-se em parte ao fato de referir-se a quatro fenômenos que se sobrepõem parcialmente. Assim, globalização denota a emergência (mais exatamente a crescente percepção) de problemas globais que afetam todos os passageiros da espaçonave Terra, independentemente de estarem viajando na primeira ou terceira classe (embora as implicações de cada categoria sejam distintas): a mudança climática causada pela emissão dos gases do efeito estufa, pandemias como a Aids (2), dependência de drogas, terrorismo e, por último, mas não menos importante, a exclusão social como um fenômeno mundial. 
A história nos pregou uma peça cruel. O rápido crescimento econômico, através de seus efeitos de propagaçã o, deveria supostamente assegurar prosperidade a todos. Nos países periféricos pós-coloniais, a expansão do setor moderno gradualmente absorveria, acreditava-se, toda a força de trabalho do setor tradicional em vias de extinção. Em vez disso, os processos de dualização assumiram o controle dos países industriais avançados e o espectro do apartheid social ameaça os países ricos e pobres sem distinção.

Mas globalização significa também pensamento global, enxergar o mundo como um todo. O globalismo sempre permeou as doutrinas imperialistas e moldou as políticas das grandes potências, das quais só resta uma em cena no presente após a morte da União Soviética e o deslocamento do sistema internacional bipolar. Num único e trágico século, duas guerras mundiais e muitas outras de natureza mais restrita resultaram da colisão dos empreendimentos globais conflitantes (Hobsbawn, 1994).

O universalismo, herança freqüentemente traída do iluminismo europeu (3), é o pólo oposto ao globalismo como aqui definido. Afirma a existência de um conjunto de valores perenes compartilhados por todos os seres humanos, reverenciado na Carta Régia da Organização das Nações Unidas e no conjunto dos direitos humanos. Esses valores devem informar todas as medidas tomadas pelos governos e organismos internacionais voltados para a promoção dos objetivos fundamentais da paz e do desenvolvimento. Levado ao seu extremo lógico, o universalismo postula o estabelecimento de um governo mundial ou, no mínimo, de uma confederação funcional de organismos internacionais, descentralizados no nível operacional e centralizados no nível de definição de políticas, com o objetivo último de constitutir uma soberania planetária descentralizada (Tinbergen et al., 1976:84).

Finalmente, em senso mais restrito, a globalização é usada para descrever "um processo pelo qual os produtores e investidores se unem cada vez mais como se a economia mundial consistisse em um único mercado e área produtiva com subsetores regionais ou nacionais, e não em um conjunto de economias nacionais vinculadas pelos fluxos de comércio e investimento" (Unctad, 1996:6).

Os globalizadores mais extremados (4) fingem que o processo avançou até o ponto de se tornar irreversível e de tal forma avassalador que priva os Estados nacionais do poder efetivo de regular as suas economias. As únicas duas forças que importam são os mercados globais e as empresas transnacionais. Nenhuma delas pode ficar sujeita à governança pública ativa. Contudo, essa visão é contestada no bem articulado livro de Hirst \& Thompson (1996), Globalization in question.

Para eles, globalização é, até certo ponto, um mito (5). A presente economia altamente internacionalizada não tem precedentes (6). O número de empresas genuinamente transnacionais é relativamente pequeno. A maioria das empresas que faz transações multinacionais tem base nacional e mantém íntimo relacionamento com seus respectivos governos. A mobilidade do capital não está produzindo transferência maciça de investimento e emprego dos países avançados para aqueles em desenvolvimento. Longe de ser genuinamente global, a economia mun- 
dial está concentrada na Tríade (América do Norte, Europa, Japão). As principais nações avançadas continuam a ser dominantes. Cerca de $80 \%$ do comércio mundial é realizado entre os países da Organização para a Cooperação e Desenvolvimento Econômico (Organization for Economic Cooperation and Development-OECD). O grupo das cinco principais economias responde por $70 \%$ do investimento direto estrangeiro, cuja importância muitas vezes é superestimada. De fato, o desenvolvimento recente mais significativo refere-se à formação de blocos econômicos regionais, como a União Européia, o Nafta e, ultimamente, o Mercosul.

O mito da globalização serve a um duplo propósito:

- validar a noção de que finalmente emergiu uma ordem internacional (7), tornando obsoletas as afirmações formuladas nos anos 70 pelo movimento não-alinhado e pelo grupo dos 77 ;

- minar os esforços dos Estados-nação para melhorar sua capacidade de regulamentar suas economias e traçar estratégias de desenvolvimento.

Hirst \& Thompson (1996:170) acreditam que a economia internacional ainda pode ser controlada e as estratégias de desenvolvimento nacional não perderam sua relevância. Uma das principais discussões de seu livro é que "os Estados-nação têm um papel significativo a desempenhar numa governança econômica, tanto no nível dos processos nacionais como internacionais".

Ainda assim, a condição é abordar as perguntas certas. O citado relatório da Unctad (1996:7) declara que a "globalização é o produto da liberalização". É significativo que seu primeiro capítulo tenha o título "Comércio e desenvolvimento numa economia mundial liberalizada e globalizante". A globalização é um processo alimentado pela liberalização compreendida como fato consumado (8).

O que sobraria para os Estados-nação, no tocante à regulamentação, numa economia plenamente liberalizada, interna e externamente? Felizmente, até agora, nunca existiu uma economia puramente de não-intervençã o, na qual os recursos fossem inteiramente alocados pelo mercado sem restrição alguma, sob condições de competição ilimitada. Como observou Hobsbawn (1994:563-565), tal contra-utopia ao socialismo real colapsado é também uma bancarrota demonstrável. Todos os milagres do século XX foram obtidos não através da não-intervenção, mas contra ela. Uma questão mais séria do que a fragmentação dos dois extremos polares é a desorientação das políticas e programas de caminho médio, que conseguiram permanecer pragmaticamente públicos e privados, de mercado e de planejamento, de Estado e de empresa.

Voltemo-nos agora ao desenvolvimento.

Confrontada com o problema global de pobreza, desemprego e exclusão social, a Declaração de Copenhague reafirmou o compromisso da Organização das Nações Unidas com o conceito de desenvolvimento sustentável, no qual as dimensões social, econômica e ambiental estão intimamente entrelaçadas (Nations Unies, 1995:4). O desenvolvimento, segundo entendemos hoje, é um conceito abrangente diferente de crescimento econômico, ainda considerado uma condição 
necessária, mas de forma alguma suficiente, incluindo as dimensões ética, política, social, ecológica, econômica, cultural e territorial, todas elas sistematicamente interrelacionadas e formando um todo. A natureza processual do desenvolvimento exige, além disso, que se leve em consideração sua sustentabilidade (perenidade) para satisfazer o postulado ético da solidariedade diacrônica com as futuras gerações, simétrico ao postulado da solidariedade sincrônica com a geração presente que, por sua vez, explica a primazia das considerações sociais na determinação dos objetivos de desenvolvimento (Sachs, 1993).

Embora introduzida no debate por questões ambientais, a sustentabilidade tem tantas facetas quanto o próprio desenvolvimento. Sugere-se que, dada a multiplicidade e por vezes a redundância dos adjetivos sucessivamente adicionados ao desenvolvimento no curso de um debate que já dura meio século - o mais recente sendo o bumano (9) -, uma denominação melhor poderia ser desenvolvimento integral (10). Integral é uma maneira sintética de referir-se a todos os atributos do desenvolvimento, indicando ao mesmo tempo que todas as dimensões pertinentes são apreciadas em suas inter-relações, de forma que o modelo conceitual seja completo e holístico.

\section{O cenário (11)}

Um tecnocrata marciano que desembarcasse em nosso planeta, utilizando a estatística média per capita, chegaria a uma conclusão bem otimista sobre a perspectiva enfrentada por seus habitantes.

Graças ao progresso da ciência e da tecnologia já obtido, a era da fartura está dentro do campo visual. As necessidades básicas de todos os seres humanos poderiam ser facilmente satisfeitas com uma reduzida carga de trabalho, de forma a liberar o tempo das pessoas para atividades culturais, espirituais e lúdicas mais congeniais com a singularidade da espécie humana. Embora ainda restem sérias incertezas quanto aos impactos ambientais de algumas tecnologias em uso e quanto à queima excessiva de energia de combustível, os cientistas deveriam receber a tarefa de encontrar soluções alternativas.

Não obstante, a realidade está longe deste quadro róseo. O mundo foi engolido por profunda crise social, agravada pela dilaceração ambiental. São inúmeras as suas causas:

- as desigualdades intrínsecas ao funcionamento dos sistemas econômicos, tanto internamente às nações quanto entre elas, levando simultaneamente à acumulação sempre crescente de recursos nas mãos de uma minoria e às privações generalizadas entre os grandes grupos da população; a dilaceração ambiental ocorre em ambas as extremidades do espectro: a minoria abastada com seu presente estilo de vida entrega-se ao consumo excessivo de recursos escassos não-renováveis; a maioria espoliada, para sobreviver, exige demais dos sistemas de suporte à vida aos quais tem acesso insuficiente;

- os padrões de uso de recursos terrivelmente esbanjadores e ambientalmente descuidados: contínua festança representada pelo empilhamento de arma- 
mentos, excessivos custos de transação dos sistemas sócio-econômicos e políticos (12), paroxismo da destrutibilidade das capacidades produtivas incitada pela busca obsessiva de competitividade, acelerada obsolescência inerente aos equipamentos e os assim chamados bens de consumo duráveis $[$ sic $]$;

- as prioridades distorcidas da pesquisa tecnológica, voltada para a demanda que pode ser solucionada e não para a satisfação das necessidades básicas;

- acima de tudo, a pior forma de perda irreversível representada pelo desperdício de vidas humanas de todos aqueles privados de seu direito de trabalhar, de ter um meio de vida decente e de manifestar os potenciais presentes em todo ser humano. Nas sociedades modernas o pobre tornou-se cada vez mais inútil e descartável (Kothari, 1993); sua difícil situação é feita de alienação e exclusão mais que de exploração.

Assim, as raízes da crise social e ambiental não repousam na escassez de recursos, nem na explosão populacional. Os não-consumidores não podem ser responsabilizados pelo excesso de consumo de energia fóssil e de outros recursos. É claro que a transição demográfica é desejável, já que um crescimento exponencial da população humana num planeta infinito não pode ser sustentado para sempre. Mas a ligação causal entre crescimento populacional e pobreza funciona em ambas as direções. Dessa forma, para quebrar o círculo vicioso entre os dois, erradicar a pobreza, melhorando as condições sociais é a prioridade primeira.

Importante característica da presente crise é que ela afeta, embora de diferentes formas e com intensidade desigual, os três grupos de países: o Sul, o Leste pós-socialista e os países industrializados do Norte, assolados pelo desemprego estrutural provocado pelo crescimento do número de desempregados e pelo desvio dos recursos de uma economia real para a grande ciranda financeira.

De longe o evento mais espetacular do final do século XX foi o súbito colapso da União Soviética e a falta de confiança em uma economia compulsória de planejamento central, paradoxalmente num momento em que poderia pelo menos contar com o suporte técnico de poderosos computadores. Os países pós-socialistas depararam-se com a assustadora tarefa de realizar, simultaneamente, ajuste estrutural, profunda reestruturação da economia e completa retificação das instituições políticas e econômicas, enfrentando ao mesmo tempo a perspectiva de desemprego em massa e lidando com grave crise ambiental.

Ainda assim, sua difícil situação e o fracasso de seu sistema sócio-econômico não constituem uma prova às avessas da excelência do capitalismo. O bem-estar social na Europa ocidental e do norte - um símbolo de capitalismo civilizado e socialmente sensível - está exibindo sinais de esgotamento, incapaz de resistir à pressão combinada de baixas taxas de crescimento (13) e de progresso técnico que desloca a mão-de-obra. Os sistemas de bem-estar social funcionaram bem, já que não foram excessivamente pressionados a dar a sua contribuição sob condições de rápido crescimento e emprego quase total. Mas agora, quando a necessidade de proteção social é mais premente, estão desmoronando devido ao seu custo, para 
não falar do fato de que dar simplesmente ao desempregado a pensão governamental não os protege contra a exclusão social e a perda da dignidade (14). Em nossas sociedades, o trabalho ainda tem importante função de socialização (Apêndice 1) e a redistribuição de sua carga por meio da redução do tempo de trabalho não constitui, em si, solução satisfatória.

A exclusão social, a segregação espacial, as tensões étnicas e a dualização das economias - temas outrora reservados à discussão das sociedades pós-coloniais adquiriram pertinência universal. Um grave déficit da democracia econômica e social tornou-se um desafio comum do Sul, do Leste e também do Norte, sem soluções fáceis à vista.

Cada vez mais, a configuração internacional age mais como obstáculo do que como facilitador. A economia mundial passou por uma transformação estrutural executada por três desacoplamentos (Drücker, 1986): o divórcio entre o crescimento da produção e a criação de oportunidades de trabalho; a lacuna entre o PIB e o volume de matérias-primas e mercadorias necessárias para produzi-lo; o vínculo entre a economia real e a esfera da especulação financeira expandido de maneira totalmente descontrolada.

A elevação da produtividade é naturalmente bem-vinda, com a condição de ser corretamente administrada em termos de uma partilha eqüitativa do trabalho socialmente necessário e do produto obtido. Mas não é este o caso no presente. A definição de preços das mercadorias exige acordos internacionais e esquemas de estabilização, que 40 anos de discussões não conseguiram realizar. O impasse NorteSul não mostra sinais de enfraquecimento. A ausência de controles sobre os mercados financeiros globais constitui a fragilidade básica das instituições de Bretton Woods.

Índices de crescimento e desemprego enganosos intensificam a luta das empresas pelos mercados. A competitividade está sendo buscada a todo custo, sem distinção entre suas fontes legítimas e espúrias, tais como salários achatados, preços muitos baixos de energia e de matérias-primas e exploração predatória dos recursos naturais (15). Sempre que deixadas à livre interação das forças de mercado, as empresas exteriorizam os custos sociais e ambientais da produção, tratando de aniquilar as regras da eqüidade social e da prudência ecológica. É por esse motivo que a determinação dos limites para a liberalização, a redefinição do papel regulador dos Estados e o estabelecimento das regras restritivas do jogo no cenário internacional são urgentemente necessários para colocar a espaçonave Terra no caminho do desenvolvimento. Foi essa a agenda oculta da Reunião de Cúpula de Copenhague, ostensivamente devotada aos três temas inter-relacionados da luta contra a probreza, da integração social e da geração de empregos.

\section{A Reunião de Cúpula Social: uma avaliação em claro-escuro}

A Declaração de Copenhague deve ser lida juntamente com a Declaração do Rio adotada na Reunião de Cúpula da Terra de 1992. As duas foram erigidas 
em torno do conceito de desenvolvimento sustentável centrado no ser humano e consideram a erradicação da pobreza como uma condição sine que non de tal desenvolvimento.

Ambas proclamam o direito ao desenvolvimento, embora a Declaração de Copenhague, incorporando os resultados da Conferência sobre os Direitos Humanos das Nações Unidas de 1993, o faça de maneira mais explícita e solene, como parte integrante dos direitos humanos fundamentais (16). Uma maneira de reconceitualizar o desenvolvimento poderia consistir em considerá-lo em termos de universalizar a apropriação efetiva de todos os direitos humanos - civis, políticos, mas também sociais, econômicos e culturais. Tal abordagem parece oferecer vantagens teóricas e operacionais: permite escapar do estreito economicismo e, ao mesmo tempo, oferece um arcabouço para a avaliação concreta do progresso (ou regressão) obtido no árduo caminho do mal desenvolvimento ao desenvolvimento (17).

Neste contexto, o objetivo do pleno emprego, reafirmado sem ambigüidade em Copenhague, surge como um ponto central para a implementação dos direitos econômicos e sociais. Tanto é assim que o desemprego e o grave subemprego afetam $30 \%$ da força de trabalho mundial e as projeções realistas não autorizam otimismo algum, a menos que as estratégias de desenvolvimento orientadas pelo emprego substituam aquelas orientadas pelo crescimento. Nessas circunstâncias, duas atitudes foram possíveis:

- aquela adotada, creditada à Reunião de Cúpula de Copenhague, de reafirmar a centralidade do emprego pleno;

- proclamar a obsolescência da própria noção de trabalho, superada por aquela, um tanto ambígua, de atividade e transigir em mais uma exortação sobre a necessidade de mudança fundamental no paradigma civilizacional. Embora reconhecendo inteiramente a importância do último debate para a formulação de soluções a longo prazo (Apêndice 1), a geração de emprego e de auto-emprego aqui e agora deveria ser considerada a pedra angular das estratégias de desenvolvimento significativas. Ela deveria ser utilizada como o ponto de partida em sua formulação, em vez de ser tratada como mero resultado das decisões relacionadas ao crescimento da produção e da produtividade da mão-de-obra, subordinado à busca implacável da competitividade através de uma destruição criativa (18) em contínua aceleração. Sugere-se que a perspectiva de geração de emprego e auto-emprego através de políticas públicas apropriadas seja menos sinistra que aquela habitualmente admitida (Sachs, 1994b; Apêndice 2).

Contudo, tais políticas exigem dos Estados-nação uma capacidade de intervenção que os processos de liberalização minaram, se é que não destruíram inteiramente. Infelizmente, as Declarações do Rio e de Copenhague deixaram de levantar tal questão, condescendendo em declarações ambíguas sobre a abertura das economias e a globalização.

Embora a incompatibilidade do desenvolvimento sustentável com a ação irrestrita das forças de mercado tenha sido repetidamente realçada no trabalho 
preparatório para a Reunião de Cúpula da Terra (19), a Declaração do Rio não abordou o tema explicitamente, limitando-se a pedir aos Estados que "reduzam e eliminem os padrões não-sustentáveis de produção e consumo". Além disso pediu em termos muito genéricos que os Estados "promovam um sistema econômico internacional corroborativo e aberto que levem a um crescimento econômico e a um desenvolvimento sustentável em todos os países", como uma maneira de evitar a questão.

A Declaração de Copenhague assume postura a favor de mercados dinâmicos, abertos e livres, reconhecendo ao mesmo tempo a necessidade de intervir nesses mercados "o quanto necessário for" (seja qual for o significado dessa afirmação) para prevenir ou corrigir seus fracassos. Menciona várias vezes a liberalização como uma solução, nunca como parte do problema, como deveria ser (Guimarães, 1996).

Em particular, os signatários da Declaração comprometem-se a acelerar a liberalização do comércio e de investimentos para favorecer um crescimento econômico sustentável e a geração de empregos. A Declaração parte do pressuposto que o aumento dos rendimentos, o crescimento do emprego e a expansão do comércio irão se reforçar reciprocamente. Ela propõe-se a monitorar, nos países em desenvolvimento, o impacto da liberalização do comércio sobre a maior satisfação das necessidades básicas da população, aparentemente pressupondo que tal impacto só poderá ser positivo.

O Programa de Ação declara que a globalização e o rápido progresso técnico fortalece a mobilidade da mão-de-obra, criando novas possibilidades de emprego "tornando, ao mesmo tempo, o futuro incerto" (?). Essa é uma maneira bem peculiar de abordar a questão do aumento dos sem-emprego e dos fenômenos de desindustrialização que ocorreram em diversos países do Terceiro Mundo e póssocialistas, como uma conseqüência da abertura sem critérios de suas economias.

A liberalização e a globalização não são um mal absoluto nem o atalho mágico para o reino da prosperidade e felicidade. Produzem ganhadores e perdedores dentro dos países e entre países, um Norte global e um Sul global, cujas fronteiras cruzam todas as nações. A lacuna entre eles se amplia. Os ricos e pobres estão vivendo em mundos cada vez mais separados (20).

Essa tendência não será revertida pela mera continuidade dos processos de liberalização e de globalização em sua forma atual. Tais processos deverão ser colocados sob controle mais restrito - nacional e internacionalmente - e submetidos a regras do jogo mais rígidas. Copenhague pecou por omissão. Não analisou com suficiente profundidade as causas do mal. Conseqüentemente, viu-se presa numa versão moderna dos trabalhos de Sísifo: políticas sociais reativas trazendo alívio às populações vitimadas afetadas pelo desemprego e pela exclusão, mas não ao desemprego nem à exclusão (21).

Mas, para concluir este balanço de Copenhague com uma nota mais alegre, a Reunião de Cúpula Social criou um momentum político que, esperamos, trará para o debate as questões certas. É chegada a hora de revelar a agenda oculta. 


\section{Retificando a governança nacional}

De acordo com Broad \& Cavanagh (1995:24), os mercados globais integram cerca de um terço da humanidade, a maior parte deles nos países ricos, mais a elite dos países pobres. Por outro lado, a lacuna Norte-Sul está se estreitando para cerca de uma dúzia de países, embora continue a se alargar para mais de 100 outros países. "Sem uma grande mudança na política, o mundo do século XXI será o do apartheid econômico".

Quais serão os poucos e afortunados países em desenvolvimento que aproveitarão os benefícios trazidos pela integração com a economia mundial por meio da globalização? Para Nayyar (1995:26), os únicos países com chances são aqueles que fincaram os fundamentos necessários para a industrialização e o desenvolvimento. Para tanto, as formas estratégicas de intervenção do Estado são essenciais, associadas à criação de instituições capazes de regular, governar e facilitar o funcionamento dos mercados (22). Em sua ausência, a globalização irá reproduzir, uma vez mais, um desenvolvimento desigual.

Embora a globalização tenha reduzido a autonomia do Estado-nação, resta certo grau de liberdade que deve ser usado para criar um espaço econômico para a busca dos interesses nacionais e objetivos de desenvolvimento.

O mesmo é verdadeiro para Estados-nação em países industriais. Os trabalhadores descontentes e marginalizados pela economia global precisam do Estado-nação "como um amortecedor da economia mundial" observa Kapstein (1996:16), queixando-se da morte dos governos. Para ele, "o destino da economia global repousa, em última instância, nas políticas internas de seus Estados constituintes".

Em seu relatório sobre a globalização e liberalização, o secretário geral da Unctad insiste no papel do Estado em proporcionar um ambiente apropriado à empresa privada, em lidar com as questões externas ambientais e em abordar as questões da pobreza e da distribuição de renda. Esta versão leve do intervencionismo é declarada na certeza de que as forças do mercado constituem o meio primário para a alocação de recursos e a organização da atividade econômica. Ela cai dentro do âmbito dos modelos europeus de governança inspirados na social-democracia (23).

Acredito que precisemos de uma versão mais poderosa para enfrentar os atuais desafios, questionando um dos princípios básicos do paradigma da democracia social: a possibilidade de garantir eqüidade por redistribuição de renda sem interferir nos problemas de produção e consumo.

No mundo real, que não lembra o modelo ideal da perfeita competição e transparência democrática, as assim chamadas forças de mercado (e os grupos poderosos por trás delas) tendem a promover um padrão perverso de crescimento através da desigualdade ou mesmo crescimento com des-desenvolvimento (Sachs, 1996). Em algum ponto, essa tendência precisará ser interrompida devido aos seus efeitos sociais destrutivos e ao custo excessivo das políticas cujo objetivo é meramente o seu alívio (não o próprio objetivo glorioso) (24). O que realmente importa é a dis- 
tribuição primária de renda inerente ao paradigma da produção, a estrutura de emprego correspondente e o acesso aos bens e aos recursos.

De fato, a igualdade de chances, outro princípio do paradigma da democracia social, só poderá ser alcançada pela democratização do acesso aos equipamentos coletivos (bens) como habitação, transporte, ambiente urbano, crédito, lado a lado com educação e saúde (Fitoussi, \& Rosanvallon, 1996:210, 228). Nesse contexto, percebe-se a importância de um conceito central ao modelo francês: serviços públicos nem inteiramente públicos, nem inteiramente privados, "uma terceira via negociada baseada na redefinição das relações públicas/privadas" (Rachline, 1996:28).

Ao mesmo tempo, faz-se necessária uma advertência com relação à valorização excessiva do impacto da educação como uma avalanca para o emprego. $\mathrm{O}$ treinamento por si só não irá gerar empregos. A quem treinar? Para quais empregos? Criados por quem? A lei de Say e a economia de oferta não funcionarão na era da informação; não mais do que funcionaram até agora (25).

Outra poderosa razão para modificar a produção e os padrões de consumo - numa tarefa ainda mais ousada dado o presente equilíbrio de poder - origina-se de considerações ambientais. O consumismo, tal como praticado nos países industrializados, com seu uso esbanjador de energia fóssil, não é sustentável a longo prazo; sua reprodução no Sul, para o benefício de suas elites, não é possível sem que mantenha um grave apartheid social.

A necessidade de mudar os padrões de consumo e o estilo de vida dos ricos para tornar possível o avanço econômico e social para os pobres vem sendo proclamada em várias conferências internacionais, desde Estocolmo e incluindo a Reunião de Cúpula de Copenhague. Tanto a Declaração quanto o Programa de Ação examinam a principal causa da degradação ambiental nos padrões não-sustentáveis de consumo e produção, principalmente nos países industriais. Mas, até onde eu saiba, pouco se fez até agora além do reconhecimento retórico do problema e da exortação moral et pour cause. Nas sociedades de mercado, os Estados hesitam, por razões doutrinárias (a soberania do consumidor), em utilizar os meios de regulação que lhes são disponíveis (sistemas fiscais, investimento público etc.). Quanto às economias anteriormente de planejamento centralizado, elas usaram sua capacidade de maneira inteiramente equivocada para influenciar os padrões de consumo e enfrentar de forma adequada o desafio ambiental.

A menos que se considere o colapso das economias centralizadas como sendo uma prova às avessas da excelência do modelo capitalista liberal (o que seria um disparate), o desafio diante de nós é repensar em sua totalidade as modalidades de regulação das economias mistas, mais do que escolher entre uma gama de modelos de capitalismo existente. Praticamente todos os países pós-comunistas, com a possível exceção da China, escolheram o caminho da imitação, e não um caminho inovador, perdendo assim uma oportunidade histórica. Contudo, o futuro precisa ser inventado. Heilbroner \& Milberg (1995) estão certos quando apontam uma crise de visão no pensamento econômico moderno. Essa é uma tarefa demasiado ambiciosa para ser abarcada neste artigo (26). Deverei me limitar a enunciar as perguntas que poderiam servir como pontos de partida para tanto: 
- Qual Estado, para qual desenvolvimento?

- Como articular o desenvolvimento interno com uma inserção soberana na economia mundial (27)?

- Seria o planejamento nacional ainda relevante e, em caso afirmativo, sob que forma (28)?

- Que conteúdo deveria ser dado à democracia além de uma mera obediência às regras do jogo da democracia representativa?

- Como obter novas formas de parceria entre o Estado, a sociedade civil e o mundo dos negócios, de forma a fortalecer e realizar todo o potencial das iniciativas locais e das ações civis?

- Na ausência de uma ordem internacional eqüitativa e eficiente, que tipo de salvaguardas nacionais são necessárias para proteger a economia contra os efeitos destrutivos e deletérios das decisões tomadas por agentes econômicos e financeiros externos (29)?

Tais questões nos levam ao próximo ponto.

\section{Globalização e governança internacional}

Eqüidade nas relações econômicas internacionais exige regras do jogo favoráveis ao parceiro mais fraco (Myrdal). O Unctad foi erigido sobre tal princípio. A igualdade formal entre parceiros de força desigual cria, pelo contrário, relações altamente assimétricas de domínio do mais fraco pelo mais forte. Ainda assim, essa é a direção para a qual o sistema internacional está se dirigindo depois da derrota das propostas para o NIEO, formuladas pelos países em desenvolvimento nos anos 70 .

$\mathrm{Na}$ sua presente forma, o sistema é ineficiente e desigual, incapaz de civilizar os processos de globalização e auxiliar de forma eficaz os esforços de desenvolvimento. É urgentemente necessário remodelar a ordem internacional, um empreendimento complexo, excessivamente difícil e demorado. Enquanto isso, confiar nas salvaguardas internas continua sendo a principal opção.

A tirania dos mercados financeiros internacionais é talvez a primeira prioridade. O Fundo Monetário Internacional, o IBS (Basiléia), o Banco Mundial e os bancos centrais são incapazes de colocá-los sob controle. Os governos, que liberalizaram os mercados financeiros, acham muito difícil resistir às andanças do capital volátil e às explosões de especulação (30). O crescimento fenomenal das transações financeiras privadas, completamente desvinculadas da economia real, desvia os recursos do investimento produtivo e pressiona para cima as taxas de juros reais em níveis sem precedentes; o investimento em infra-estrutura é a primeira vítima.

A vulnerabilidade do sistema é tão evidente que alguns operadores financeiros com larga visão exigem a retificação das instituições de Bretton Woods e a formulação de regras mais rígidas. Para Soros (1996:10), a economia de hoje repousa sobre uma base muito frágil. Os mercados são imperfeitos e poderão ser levados ao colapso na ausência de mecanismos fortes que coloquem ordem na economia 
globalizada. "Uma sociedade aberta que não seja regida por leis é inviável - seja um país ou um planeta. No presente, as finanças internacionais não obedecem a lei alguma. Quando uma atividade escapa ao reino da lei, é a força que prevalece".

Já há 20 anos, James Tobin sugeriu um imposto sobre transações em moeda estrangeira (31), cujo giro diário cresceu hoje para cerca de US\$ 1,2 trilhões (32). Tal imposto refrearia a especulação de curto prazo. Além disso, geraria enormes somas de recursos. Um imposto de um por mil $(0,1 \%)$ - um centavo sobre um centavo sobre um centavo - produziria cerca de US\$ 150 bilhões, suficientes para garantir em escala mundial a implementação da Agenda 21 e finalmente fornecer à Organização das Nações Unidas uma fonte automática de financiamento (33).

A Reunião de Cúpula de Copenhague praticamente ignorou a proposta de Tobin, limitando-se a um apelo por auxílio externo adicional. Enquanto isso, a razão entre o ODA e o PIB de países industriais reduziu-se, atingindo nível recorde. Sob a pressão da maioria republicana no Congresso, os Estados Unidos estão se desobrigando do auxílio multilateral.

Sem um sistema monetário internacional verdadeiramente importante, taxas cambiais relativamente estáveis e moedas alinhadas, um sistema comercial não consegue operar de maneira ordenada; uma grave deficiência do sistema, que está sendo criada em torno da Organização Mundial do Comércio (OMC), mas não é, de forma alguma, a sua única fraqueza. Para Dubey (1996:130), ex-embaixador indiano para as Nações Unidades e o Acordo Geral de Tarifas e Comércio ( GATT), "o sistema de comércio internacional que emergiu do Círculo do Uruguai é uma combinação de multilateralismo, regionalismo discriminatório e unilateralismo arbitrário altamente qualificados e apenas parcialmente liberais". O regime dos Direitos de Propriedade Intelectual é um movimento que se distancia do liberalismo e da competição. O comércio na agricultura ainda continuará sendo, em grande parte, uma mistificação. Nenhum regime internacional estudou a possibilidade de inibir as práticas comerciais restritivas de TNCs. Os esquemas de integração regional tenderão a marginalizar os países que ficarem fora desses acordos. Não é de se admirar que ele tenha dado ao seu livro o título An unequal treaty.

A consequiência lógica obtida da análise de Dubey (1996:134, 138) para a Índia é uma defesa para "retomar o caminho do crescimento autodependente sem que se isolem do resto do mundo". A integração com a economia global deve ser seletiva, o desenvolvimento de capacitação tecnológica reforçado, a liberalização financeira vir por último na seqüência das reformas econômicas. "É necessário resistir a todas as tentativas de se usar os poderes financeiros do FMI e do Banco Mundial para fortalecer as disciplinas da OMC sobre os países em desenvolvimento e de utilizar as sanções da OMC para fortalecer as condicionalidades do FMI/ Banco Mundial".

Vários pontos dos acordos de Marrakech devem ser renegociados, a começar pelo TRIPS. A Índia deveria tomar a iniciativa de introduzir na agenda de negociação um regime internacional sobre a política de competição para controlar as práticas comerciais restritivas das corporações internacionais. Ao mesmo tempo, 
devem ser feitos esforços no sentido de resistir à introdução na OMC de questões que seriam melhor abordadas por outras organizações do sistema das Nações Unidas.

As opiniões de Dubey são representativas de grande parte da opinião pública informada do Sul. É necessário estudá-las com cuidado, caso tenhamos a intenção de desfazer o presente impasse Norte-Sul. Em particular, recomenda-se moderação com relação à assim chamada cláusula social. Independentemente das intenções de seus proponentes, do ponto de vista do Sul, tal cláusula parece mais um instrumento de protecionismo oculto dos países industriais (34).

A reforma das instituições de Bretton Woods, que já deveria ter sido realizada há muito, e a agilização da OMC são partes integrantes de um problema maior: a reorganização de todo o sistema da Organização das Nações Unidas ao qual pertencem as instituições de Bretton Woods de direito, mas não de fato (35). O Sul certamente está interessado em fortalecer e democratizar a Organização das Nações Unidas (36), mas não parece ser a intenção dos Estados Unidos e dos países da OECD, retórica que não se sustenta. A perspectiva é preocupante.

Em vez disso, o G7 - organismo cuja legitimidade é questionável e que fala somente para a Tríade - ocupou o vazio criado pela fragilidade do sistema da ONU. Sob sua orientação, é provável que uma globalização sem reservas continue, somente temperada pelas políticas dos Estados-nação (37).

\section{Rumo a novos contratos sociais?}

Uma avaliação realista do presente impasse não deverá nos desviar de produzir uma visão ousada da direção para a qual queremos caminhar. Democracia é um valor fundamental (Sen), ao passo que os mercados pertencem à esfera instrumental. O perfeccionismo da democracia é, em grande medida, sinônimo de desenvolvimento redefinido em termos de apropriação efetiva de todos os direitos humanos, por todos.

Em artigo iluminado, Friedmann (1996) argumenta que, no nível prescritivo, é necessário um novo contrato social, baseado no direito à subsistência, que leve a um relacionamento triangular entre o Estado, as associações civis e os núcleos familiares (a economia doméstica é considerada por ele como um centro para a produção da subsistência). Friedmann propõe um decálogo de direitos civis (quadro a seguir) e sugere que os Estados deveriam se comprometer a honrar tais direitos antes de dar atenção a outras reivindicações.

"Nesta perspectiva, portanto, o crescimento econômico não é mais considerado como a busca cega pelo crescimento por si só, mas como uma expansão das forças produtivas da sociedade cuja finalidade é que toda a população alcance direitos civis plenos. O crescimento econômico torna-se, portanto, vinculado a uma meta social específica e exige intervenção do Estado na anárquica atuação das forças de mercado. O novo contrato social dá à teoria econômica um propósito moral, transformando-a de ciência utilitária e excessivamente individualista em ciência deontológica". 
Decálogo dos direitos civis

1. Nascimento assistido por profissional
2. Espaço de vida seguro e protegido
3. Dieta adequada
4. Assistência médica de preço acessível
5. Boa educação prática
6. Participação política
7. Vida economicamente produtiva
8. Proteção contra o desemprego
9. Velhice digna
10. Enterro decente

Fonte: Friedmann, (1996)

Friedmann (1996:168) defende delegar o poder às comunidades locais e considera a auto-organização dos pobres como fundamental para conseguir uma sobrevivência coletiva. Mas, ao mesmo tempo, enfatiza a necessidade de ajuda externa, especialmente pelo Estado, para obter resultados satisfatórios em escala compatível ao tamanho do problema. O setor voluntário não pode enfrentá-lo sozinho. "Sem o envolvimento direto do Estado, não pode haver fuga da pobreza em massa e da perda de poder". Ele mostra ainda as limitações do novo localismo. Os níveis regional, nacional e internacional também estão envolvidos (38).

O que poderia ser feito para realizar este tipo de parceria entre a sociedade civil e o Estado? Para Friedmann, a única esperança está no lançamento de movimentos de protesto político exigindo que as reivindicações de subsistência das pessoas espoliadas sejam transformadas num direito humano fundamental. Tal expectativa poderá se mostrar uma avaliação realista das limitações das abordagens menos radicais. Isso não quer dizer, contudo, que não devamos tentar colocar o novo contrato social na agenda da negociação política, complementando-a com um contrato natural (Serres, 1990).

Ao mesmo tempo, devemos reconstruir o sistema internacional com base num contrato mundial a ser idealizado seguindo as linhas sugeridas por Ricardo Petrella e o Group of Lisbon (1993) bem como pela Foundation pour le Progrès de l'Homme. Esse contrato deveria finalmente criar as condições para um co-desenvolvimento simétrico entre Sul e Norte, preparado pela co-reflexão; a despeito dos esforços do Unctad e outros organismos da $\mathrm{ONU}$, tal co-reflexão não produziu ainda um documento convincente de um novo co-pacto Norte-Sul (39).

\section{Para onde vai a Europa? \\ Um comentário final sobre o tema}

Temos razões de estar orgulhosos de nossos Estados de bem-estar social e de resistir ao modo norte-americano, mesmo que, pelas razões já expostas, devamos reconhecer as limitações do paradigma da democracia social e buscar meios 
inovadores de reconquistar o pleno emprego e mudar de Estados de bem-estar social para sociedades de assistência.

Nossa ambição deverá ser uma tentativa de humanizar a globalização que, em sua presente forma, é a lei da selva, um sistema no qual são sempre os ricos que ascendem enquanto os pobres ficam mais pobres (Guigou, 1996). Por isso, precisamos definir um projeto societário europeu que consiga se desdobrar num projeto de civilização mundial (40). O futuro da Europa dependerá de nosso sucesso ou fracasso neste empreendimento, que exige que nos mobilizemos contra a força motriz por trás da globalização: "o capitalismo mundial e seus apóstolos liberais" (Gauron, 1996). A União Européia correrá o risco de se transformar no cavalo de Tróia da globalização socialmente destrutiva, se falhar em se dar um forte fundamento social comum e, para fins práticos, em limitar suas ambições àquelas de um mercado comum.

Uma vez mais, a persistir o contexto atual, as perspectivas não parecem atraentes. Observadores sensíveis do outro lado do Atlântico consideram que a Europa é uma grande ilusão, quase um mito, "mais uma noção geográfica que uma resposta" aos seus problemas políticos e sociais (Judt, 1996). De acordo com Suleiman (1996), há um total o divórcio entre a Europa real e a mítica e retórica. O discurso está na Europa social, mas a Europa que foi construída é liberal. "Apesar dos esforços sinceros de alguns europeus eminentes, foi a Europa da senhora Tatcher que conseguiu predominar". O capitalismo venceu. Visto do Sul, a Europa parece um grupamento voltado para dentro, com políticas agrícolas altamente protecionistas e fortes interesses neocoloniais (41).

A esquerda européia tem um longo caminho a percorrer para reverter tal situação.

Notas

1 Em curto espaço de tempo, os países ficaram sucessivamente conhecidos como subdesenvolvidos, menos desenvolvidos e, finalmente, em desenvolvimento, ao mesmo tempo em que suas condições reais não mudaram muito.

2 A unificação microbiana do mundo precedeu à criação de uma economia mundial.

3 Para uma interessante análise sobre como a herança dos Lumières está sendo pervertida no Norte, veja Guillebaud, (1995:35). O autor observa que a crítica do Sul é menos otimista sobre o pretenso universalismo de nossos valores do que sobre a infidelidade aos Lumières, "Não é a força de nossos princípios que é questionada, mas a sua traição".

4 Como, por exemplo, Ohmae (1996) ou Naisbitt (1995).

5 Veja também Bairoch (1996), Streeten (1996), Ferrer (1996a) e Guaino (1996). O último autor, comissário francês de Planejamento, insiste no fato de que o grosso das atividades econômicas e dos intercâmbios se concentra dentro de cada país: “... terminou-se por perder de vista que o coração da economia está no interior do próprio país e que o essencial se joga, antes de mais nada, na proximidade". Mais que conde- 
nar os Estados-nação, a globalização os força a competir. O planejamento continua sendo importante ferramenta de coerência, coesão e harmonização. Entre os economistas norte-americanos, Krugman (1994) denunciou repetidamente o perigo de se dar importância excessiva aos problemas de globalização em detrimento do desenvolvimento doméstico. Para um tratamento mais fundamental dos processos e teorias da globalização, veja Ferrer (1996b) e Ianni (1995). Na França, os livros que tratam da globalização seguem um caminho impressionante. Para uma análise minuciosa e equilibrada das implicações da globalização para a França, veja Cohen (1996) e Brender (1996).

6 Nayyar (1995) traça um paralelo iluminado entre os processos de globalização do último quarto do século XX e o período de 1870-1914. De acordo com o South Centre (1996a), o alcance da abertura comercial entre países industriais era então relativamente semelhante ao de hoje. Para os 16 países mais avançados, a proporção de exportações no PIB era de 18,2\% em 1900 e de $21,2 \%$ em 1913. Durante a presente era, tal proporção no PIB mundial aumentou de menos de 6\% em 1950 para $12 \%$ em 1973 e 16\% em 1992. Os números correspondentes para os países industriais são de $12 \%$ em 1973 e $17 \%$ em 1992 . O estoque de investimento estrangeiro direto no mundo como proporção da produção mundial foi praticamente igual em 1973 (9\%) e em $1992(8,4 \%)$.

7 Pronunciando-se no Centro Indiano Internacional em janeiro de 1996, o presidente do Brasil, Fernando Henrique Cardoso (1996:33), declarou: "Quer queiramos ou não, a globalização econômica é uma nova ordem internacional. Devemos aceitar esse fato com um senso de realismo. Caso contrário, nossas ações carecerão de um impacto real. Isso não equivale a uma inércia política, mas a uma perspectiva inteiramente nova sobre as formas de ação no cenário internacional".

8 Para uma análise magistral das conseqüências da liberação num país em desenvolvimento (neste caso, a Índia), veja Bhaduri \& Nayyar (1996).

9 O UNDP publica relatórios anuais sobre desenvolvimento humano e propõe um índice sintético (e até onde eu saiba, controverso) do desenvolvimento humano (veja Sachs, 1995b). De qualquer forma, uma palavra mais apropriada em inglês seria humane [bumanitário].

10 Para Perroux, desenvolvimento refere-se a "cada homem e a todos os homens".

11 Esta seção baseia-se parcialmente em Gowariker e Sachs (1995a).

12 Vários conceitos foram formulados para interpretar tais custos. Marx falou de faux frais da produção capitalista, Bataille, de la part maudite. Para um estudo pioneiro sobre os custos sociais do empreendimento privado, veja Kapp (1950, 1971).

13 Durante a década de 1960, a economia mundial cresceu à taxa de 5\%; nos anos 70, à de $3,6 \%$; nos anos 80, 2,8\%; e na primeira metade dos anos 90, apenas $2 \%$. "Em duas décadas, o capitalismo perdeu 60\% de seu momentum" (Thurow, 1996a:1). Os Estados Unidos apresentaram uma taxa média de crescimento anual do PIB de $3,4 \%$ de 1870 a 1973 e de apenas 2,3\% entre 1973 e 1993. A produção por homem/hora (produtividade) cresceu à média anual entre 2 e 2,5\% de 1870 a 1950 e foi maior que 2,5\% de 1948 a 1973; caiu a menos de 1\% de 1973 a 1993 (Madrick, 1995). A correlação entre a ascensão do neoliberalismo e o arrefecimento da economia mundial merece um estudo mais profundo. Mesmo segundo seus próprios padrões, a "sobrevivência do capitalismo mais apto" (Thurow, 1996a) que domina o cenário de hoje, é incapaz de asseverar sua superioridade. 
14 Já na década de 70, os limites do Estado de bem-estar social e a crise iminente eram perfeitamente discerníveis (Sachs, 1982). O Secretariado para Estudos Futuros então existente na Suécia foi o ponto focal para a pesquisa de formas alternativas de assistência à sociedade. Para uma revisão recente sobre esta questão, veja Balbo (1994).

15 Para um mise en garde contra a transformação da competitividade numa ideologia totalmente disseminada, veja o relatório do Group of Lisbon (1993).

$16 \mathrm{O}$ governo republicano dos Estados Unidos resistiu violentamente à própria noção de direito ao desenvolvimento. A Declaração de Copenhague e o Plano de Ação a mencionam repetidamente. Seria de se esperar, contudo, um documento substantivo melhor elaborado sobre o tema, cuja codificação está superada.

17 Contudo, mesmo o direito a ser decentemente alimentado vem sendo contestado em termos conceituais pela delegação norte-americana na recente Reunião de Cúpula de Segurança do Alimento, realizada em Roma. Sem sombra de dúvida, o establishment norte-americano não gostaria de ver a abordagem dos direitos ao desenvolvimento aplicada aos Estados Unidos, dada a espiral de queda dos indicadores sociais e de qualidade de vida em forte declínio naquele país (Miringoff, et al., 1996). Deve-se dizer ainda que, contrariamente à opinião amplamente divulgada, o verdadeiro índice de desemprego calculado corretamente nos Estados Unidos não é melhor que o da Europa. De acordo com Lester Thurow (1996b:56): "Se combinarmos os 7,5 a 8 milhões de trabalhadores oficialmente desempregados, aos 5 a 6 milhões de pessoas que não estão trabalhando, mas que não atendem a qualquer das provas de estarem ativas na força de trabalho e, portanto, não são consideradas desempregadas, e os 4,5 milhões de trabalhadores de tempo parcial que poderiam querer trabalhar em tempo integral, existirão 17 a 18,5 milhões de norte-americanos procurando por mais trabalho. Isso eleva o verdadeiro índice de emprego para quase $14 \%$. O lento crescimento também gerou enorme força de trabalho contingente de pessoas subempregadas. Existem 8,1 milhões de trabalhadores norte-americanos em empregos temporários, dois milhões que trabalham quando convocados e 8,3 milhões de empreiteiros independentes trabalhando por conta própria (muitos deles profissionais mal aproveitados que têm poucos clientes, mas se autodenominam consultores e trabalham por conta própria por serem demasiadamente orgulhosos para admitir estarem desempregados). A maioria dessas mais de 18 milhões de pessoas também está procurando por mais trabalho e melhores empregos. Juntos, esses trabalhadores contingentes respondem por outros $14 \%$ da força de trabalho".

18 Em que ponto a destruição criativa se torna contraproducente? Quando Schumpeter cunhou tal conceito, tinha em mente índices bem mais baixos de giro de capital fixo. Os computadores e outros equipamentos se tornaram moralmente obsoletos (Marx), com tamanha rapidez que um volume sempre crescente de investimentos vai para a reposição prematura, em detrimento do investimento que amplia o emprego. $\mathrm{O}$ problema se agrava pelo desvio já mencionado dos recursos financeiros, do investimento produtivo para a especulação.

19 Veja em particular as contribuições de dois vencedores do prêmio Nobel, Haavelmo e Tinbergen no volume editado por Goodland et al. (1991). Veja também Sachs (1993).

20 "Uma elite global emergente, principalmente urbana e interconectada de diversas maneiras, está acumulando grande riqueza e poder, enquanto mais da metade da humanidade é ignorada". J. Speth, administrador da UNDP, apresentando o Relatório 
de Desenvolvimento Humano de 1996 (International Herald Tribune, 16 jul. 1996), afirma que mais de três bilhões de pessoas vivem com uma renda de menos de US\$ 2 por dia.

21 Cf. Séguin (1996:26): “Terrível contra-senso: as pessoas se matam para tratar os desempregados, quando deveriam tratar do desemprego". As políticas sociais de remediação certamente são necessárias, dado o crescente número de pessoas que precisam de assistência. Mas elas não atacam o problema em suas raízes.

22 A teologia neoliberal deixa escapar um ponto fundamental defendido por K. Polanyi: os mercados sociais são construtos sociais (veja Bagnasco, 1988).

23 Para uma análise recente de modelos rivais de capitalismo, que dá continuidade ao trabalho de Schonfield \& Albert, veja Crouch \& Streeck (1996).

24 Minha postura é diametralmente oposta àquela dos especialistas da OECD, que consideram a luta contra o desemprego exigir o alargamento das desigualdades. Veja sobre este ponto Halimi (1996).

25 Veja, por exemplo, Phelps (1996) e Séguin (1996). No artigo já citado Kapstein (1990:27-28) escreve: "É estranho que o treinamento tenha se transformado na panacéia dos economistas e das autoridades públicas de todo o espectro político quando ele poderia, na melhor das hipóteses, fornecer apenas uma resposta parcial aos problemas dos trabalhadores deslocados...".

26 Em novembro de 1989, no despertar da queda do muro de Berlim, propus um projeto comparativo sobre economias mistas, resumido no Apêndice 3.

27 É necessário transcender a dicotomia entre o crescimento para dentro e para fora que busca um desenvolvimento de dentro para fora (Sunkel, 1993).

28 Pessoalmente, acredito que o colapso do planejamento centralizado não deveria ser interpretado como o fim do planejamento como tal. Todas as grandes corporações fazem planejamento estratégico. Por que o Estado-nação deveria se abster? A experiência francesa sugere que a orquestração concatenada entre todos os protagonistas do processo de desenvolvimento poderá levar a resultados interessantes, principalmente quando as partes interessadas estabelecerem entre si os vínculos contratuais. O conceito nórdico de economia negociada aponta para a mesma direção.

29 É um paradoxo da história que, esquecidos de sua experiência histórica, sob a pressão dos globalizadores, os Estados-nação aceitem desmantelar suas defesas na interface com a economia mundial, ou seja, no ponto em que são mais vulneráveis.

30 Contudo, uma política mais seletiva no nível nacional é factível, como mostram os exemplos da Coréia do Sul e de Taiwan (veja Sing, 1996, para uma interpretação detalhada de sua história de sucesso contrastada com a experiência da América Latina e para uma interpretação polêmica das opiniões do Banco Mundial com relação ao assunto). É necessário dizer que mesmo o Chile e a Colômbia conseguiram se proteger contra as idas e vindas do capital volátil.

31 Veja Haq et al. (1996) para uma análise atualizada desta proposta e sobre as controvérsias que a cercam.

32 De acordo com The Economist (13 jul. 1996), o giro diário é aproximadamente igual às reservas monetárias totais dos bancos centrais do mundo. 
33 O Secretariado do Unced estimou, em 1993, que em sua velocidade máxima, a Agenda 21 exigiria dispêndios de US\$ 625 bilhões por ano, incluindo uma transferência do Norte para o Sul de US\$ 125 bilhões na forma de Auxílio Oficial ao Desenvolvimento (Official Development Assistence - ODA), cerca de 0,7\% do PIB dos países industrializados.

34 Não pretendo dizer com isso que a imposição de padrões sociais nos países em desenvolvimento não seja importante. Pelo contrário, constitui um grande desafio para o alcance e o aprofundamento da democracia. Contudo, existem outros processos a serem abordados na questão e melhores formas de apoiar os avanços sociais no Sul do que reabsorver as práticas discriminatórias no comércio. A abolição de mãode-obra infantil é certamente importante. Mas a maioria das crianças trabalha na agricultura e em serviços, e não nas indústrias voltadas para a exportação.

Numa visão geral do debate sobre a cláusula social de um ponto de vista indiano, Hensman (1996:1033) escreve: "Se sindicalistas da Europa e da América do Norte quisessem nos convencer de que estão genuinamente preocupados com essas crianças e não apenas com os seus próprios empregos, eles deveriam nos ajudar a encontrar soluções criativas para tal problema. Talvez eles possam fazer uma campanha a favor do cancelamento da dívida que seja diretamente encaminhada aos dispêndios governamentais em reabilitação e educação dessas crianças, e um fim imediato das políticas de ajustes estruturais que levaram a aumentos na mão-de-obra infantil”.

O governador de Brasília, Cristovam Buarque, iniciou um programa muito bemsucedido, que trouxe de volta aos bancos escolares do primeiro grau 30 mil crianças de famílias necessitadas, cujos pais estão recebendo o equivalente a um salário mínimo por mês para compensar a renda perdida pelo afastamento das crianças do traba1ho. Várias outras cidades brasileiras seguiram esse exemplo. Um programa de bolsas de estudos, com financiamento internacional, para permitir que as crianças pobres abram mão do trabalho para ir à escola faria mais que chantagear a cláusula social.

35 A referência padrão sobre este tema é o excelente livro de Holland (1994).

36 A perspectiva do Sul, na reforma da ONU, já foi especificada em relatório abrangente preparado pelo South Centre (1996). O South Centre é uma organização permanente intergovernamental dos países em desenvolvimento, que trabalha em contraste com o Movimento Não-Alinhado e o Grupo dos 77. No Apêndice 4 foram reproduzidos quatro tópicos extraídos desse livro, resumindo as visões do Norte e do Sul sobre as Nações Unidas.

37 O G7 representa pouco mais de 10\% da população mundial (Singer, 1995). Sua ampliação foi sugerida (Chavagneux, 1995), mas ainda estaria muito longe de transformá-lo num organismo verdadeiramente democrático. Uma questão fundamental a ser levantada aqui é a das relações entre os membros da Tríade. Serão eles capazes de comprometer seus interesses conflitantes e exercer conjuntamente seu co-domínio sobre o restante do mundo ou, ao contrário, suas contradições irão se tornar mais nítidas? Neste último caso, surgiriam as condições, pelo menos para alguns países grandes (China, Rússia, Índia, Brasil), de praticar uma espécie de neonentralismo, com os membros da Tríade jogando um contra os outros.

38 Veja sobre a mesma questão, Madrick (1995:162): "Mas não podemos esperar que o governo local proteja nossos direitos civis duramente conquistados, cuide dos pobres ou mantenha nossa defesa nacional. Os governos locais não podem construir 
rodovias nacionais, supervisionar corporações imensas ou, mesmo, ajudar a coordenar uma superestrada eletrônica. As soluções em níveis locais desempenharão importante papel em qualquer renovação da América, mas muitos dos problemas que nos atormentam têm um alcance nacional. Renunciar a alguns de nossos direitos mais apreciados em prol das autoridades locais seria realmente perigoso".

39 O co-pacto 20:20 formulado pelo UNDP só aborda uma questão: as políticas sociais. Além disso, está aberto à forte crítica, no mínimo devido a três motivos:

- por que 20:20 e não algum outro número;

- aplicar os mesmos índices a todos os países significa desconsiderar suas singularidades;

- 10\% de um ODA em rápida retração constitui meta um tanto decepcionante no tocante aos países doadores.

40 "Para voltar a dar um sentido à construção européia - agora que no Oeste a paz foi conquistada, mesmo não sendo este infelizmente o caso no Leste de nosso continente - é necessário tentar ver como a Europa pode humanizar a globalização. Para tanto, é preciso conseguir a definição de um projeto europeu de sociedade, e é necessário que este passo seja retomado como um projeto de civilização em escala mundial, que tenha por ambição, não nivelar por baixo ou uniformizar, mas, pelo contrário, elevar em direção ao alto e deixar de viver as diferenças, as diversidades e as tradições culturais, pondo em comum aquilo sobre o que nós sabemos nos assemelhar" (Guigou, 1996:116).

41 A proporção do comércio extra-europeu no PIB europeu não é maior que $10 \%$.

Referências bibliográficas

AZNAR, G. Emploi: la grande mutation. Paris, Hachette, 1996.

BAGNSCO, A. La costruzzione sociale del mercato. Bolonha. Il Mulino, 1988.

BAIROCH, P. Globalization miths and realities: one century of external trade and foreign investiment. In: BOYER, R. \& DRACHE, D. (eds.). States against markets: the limits of globalization. Londres/New York, Routledge, 1996.

BALBO, L. From welfare State to caring society. Texto preparado para a CONFERÊNCIA INTERNACIONAL SOBRE POLÍTICAS PÚBLICAS, AÇÕES DOS POVOS E DESENVOLVIMENTO SOCIAL. Bolonha, 2-3 de dezembro de 1994.

BHADURI, A. \& NAYYAR, D. The intelligent persons guide to liberalization. Nova Delhi, Penguin Books, 1996.

BRENDER, A. L'impératif de solidarité, la France face à la mondialisation. Paris, La Découverte, 1996.

BROAD, R. \& CAVANAGH, J. Don't neglect the impoverished South. Foreign Policy n. 101, Inverno 1995-96.

CARDOSO, F.H., 1996, Os caminhos da social democracia. Brasília, Cadernos do PSDB, n 1, 1996.

CHAVAGNEUX, Ch. L'avenir des institutions de Bretton Woods: Halifax et après. Economie Internationale n. 64, p. 3-22, 4º trimestre 1995. 
COHEN, Elie La tentation hexagonale, la souperaineté à l'épreuve de la mondialisation. Paris, Fayard, 1996.

CROUCH, C. \& STREECK, W. Capitalismes en Europe. Paris, La Découverte, 1996.

De BANDT, J. et al. La France malade du travail. Paris, Bayard Editions, 1995.

DRÜCKER, P. The changed world economy. Foreign Affairs, p. 768-791, 1986.

DUBEY, Muchkund. An unequal treaty: world trading order after GATT. Nova Delhi, New Age International Ltd. Publishers, 1996.

FERRER, A., Desarrollo y subdesarollo en un mundo global: los dilemas de America Latina. IDB CONFERENCE ON DEVELOPMENT THINKING AND PRACTICE, Washington, setembro de 1996a.

Historia de la globalizacion: origenes del orden economico mundial. Buenos Aires, Fondo de Cultura Economica, 1996b.

FITOUSSI, J.P. \& ROSANVALLON, P. Le nouvel âge des inégalités. Paris, Seuil, 1996.

FRIEDMANN, J. Rethinking poverty: empowerment and citizen rights. International Social Science Journal n. 148, Unesco, jun. 1996.

GAURON, A. L'Europe, frein ou accélérateur de la mondialisation. Après-demain n. 383-384, abr./maio 1996.

GOODLAND, R.; DULY, E; SERAFY \& von DORST (eds.). Environmentally sustainable economic development: building on Brundtland. Paris, Unesco, 1991.

GUAINO, M. Le mythe de la mondialisation. Le Monde, 24 maio 1996.

GUIGOU, E. L'Europe, une chance d'humaniser la mondialisation. In: EUROPE, DÉFI DE CIVILISATION, colóquio organizado nos dias 2 e 3 de abril de 1996 no Sénat. Paris, Forum Alternatives Européennes, 1996, p. 115-120.

GUILLEBAUD, J.C. La trahison des Lumières, enquête sur le désarroi contemporain. Paris, Editions du Seuil, 1995.

GUIMARÃES, R.P. Globalización, actores socialies y democracia en América Latina. Texto apresentado no SEMINÁRIO LOS CIUDADANOS FRENTE A LA GLOBALIZACION. Santiago do Chile, 19-30 de março de 1996.

HALIMI, S. Economistes en guerre contre les salaires. Le Monde Diplomatique, jul. 1996.

HAQ, M.; KAUL, I. \& GRUNBERT, I. (eds.). The Tobin Tax: coping with financial volatility. Oxford/New York, Oxford University Press, 1996.

HEILBRONER, R. \& MILBERG, W. The crisis of vision in modern economic thought. Cambridge/New York, Cambridge University Press, 1995.

HENSMAN, R. Minimum labor standards and trade agreements: an overview of the debate. Economic and Political Weekly, 20-27 abr. 1996.

HIRST, P. \& THOMPSON, G. Globalization in question. Cambridge (UK), Polity Press/ Blackwell, 1996.

HOBSBAWN, E. The age of extreme: a history of the world, 1914-1991. New York, Pantheon Books, 1994. 
HOLLAND, S. Towards a new Bretton Woods, alternatives for the global economy. Nottingham, Spokesman, 1994.

IANNI, O. Teorias da globalização. Rio Janeiro, Civilização Brasileira, 1995.

JUDT, T. Europe: the grand illusion. The New York Review of Books, 11 jul. 1996, p. 6.

KAPP, K.W. The social costs of private enterprise. New York, Schocken Books, 1971.

KAPSTEIN, E.B. Workers and the world economy. Foreign Affairs, v. 45, maio/jun. 1996.

KOTHARI, R. Growing amnesia. An essay on poverty and the human consciousness. Nova Delhi, Viking/Penguin Books, 1993.

KRUGMAN, P. Peddling prosperity. New York, W.W. Norton, 1994.

MADRICK, U. The end of affluence: the causes and consequences of Americas economic dilemma. New York, Random House, 1995.

MÉDA, D. Le travail, une valeur en voie de disparition. Paris, Autier, 1995.

MIRINGOFF, M.L.; MIRINGOFF, M. \& OPDYCKE, S. The growing gap between standard economic indicators and the Nations social health. Challenge, jul./ago. 1996.

NAISBITT, J. Global paradox. New York, Avon Books, 1995.

NATIONS UNIES. Déclaration et programme d'action de Copenhague. New York, Sommet Mondial pour de Développement Social, 1995.

NAYYAR, D. Globalization: the past in our present. Discurso presidencial, Chandigarh, Indian Economic Association, 12-30 de dezembro de 1995.

OHMAE, K. The end of the nation State. Trad. para o francês sob o título De l'Étatnation aux Etats-régions. Paris, Duod, 1996.

PHELPS, E.S. Entrevista. Le Monde, 12 mar. 1996.

RACHLINE, F. Services publics. Economie de marché. Paris, Presses de la Fondation Nationale des Sciences Politiques, 1996.

RIFKIN, J. The end of work: the decline of the global labor force and the dawn of the postmarket era. New York, Tarcher/Putnam, 1995.

ROUSTANG, G. et al. Vers un nouveau contrat social. Paris, Desclée de Brouwer, 1996.

SACHS, I. Times-spaces of development. Paris, Diogenes n. 112, p. 75-90, 1980.

The crisis of the welfare Satate and the exercise of social rights to development. Paris, International Social Science Journal, v. XXXIV, n. 1, 1982.

Transition strategies towards the 21st century (with a foreword by Maurice F. Strong). Nova Delhi, Interest Publications for Research and Information System for the Non-Aligned and Other Developing Countries, 1993. 92p. (disponível em francês, português, italiano, japonês e polonês).

Redefining the good society: a North-South dialogue on challenges of 21 st century, em colaboração com V. Gowariker. Bombay, Economic and Political Weekly, p. 1383-1385, 4 jun. 1994a.

Population, développement et emploi. Paris, Revue Internationale des Sciences Sociales n. 141 (Population: problèmes et politiques), p. 409-426, set. 1994b. 
SACHS, I. Searching for new development strategies: the challenges of social summit. Texto preparado por ocasião da WORLD SUMMIT FOR SOCIAL DEVELOPMENT, Copenhague, 6-12 de março de 1995; Paris, Unesco, 1995. 48 p. (Most Policy Papers, $1^{\circ}$, $1995 \mathrm{a}$.

The quantitative and qualitative measurement of development: its implications and limitations. Oxford, International Social Science Journal n. 143, mar. 1995b.

Growth with development: a comment on Gert Rosenthals paper. IDB CONFERENCE ON DEVELOPMENT THINKING AND PRACTICE, Washington, setembro de 1996.

SÉGUIN, Ph. En attendant l'emploi. Paris, Seuil, 1996.

SERRES, M. Le contrat naturel. Paris, François Bourin, 1990.

SING, A. Catching up with the West: a perspective on Asian economic development. IDB CONFERENCE ON DEVELOPMENT THINKING AND PRACTICE, Washington, setembro de 1996.

SINGER, H.W. Revitalizing the United Nations: five proposals. IDS Bulletin v. 26, n. 4, p. 35-39, 1995.

SOROS, G. Entrevista. Veja, 1 maio 1996, p. 6-10.

SOUTH CENTRE. Liberalization and globalization: the issues at stake for the South and for Unctad, 1996a.

For a strong and democratic United Nations: a South perspective on UN reform. Genebra, 1996b.

STREETEN, P. Globalization and competitiveness: what are the implications for development thinking and practice? IDB CONFERENCE ON DEVELOPMENT THINKING AND PRACTICE. Washington, setembro de 1996.

SULEIMAN, E. Europe et capitalisme. Paris, Le Monde, 18 abr. 1996.

SUNKEL, O. (ed.). Development from within: toward a neostructuralist approach for Latin America. Bouder, Lynne Reinner Publishers, 1993.

THE GROUP OF LISBON. Limits to competition. Lisboa, Gulbenkian Foundation, 1993.

THUROW, L. The future of capitalism: how today's economic forces shape, $1996 \mathrm{a}$. abr. 1996b. The crusade that's killing prosperity. The American Prospect, mar./

TINBERGEN, Jan et al. (coord.). Reshaping the international order: a report to the Club of Rome. New York, E.P.Dutton \& Co., 1976.

UNCTAD. Globalization and Liberalization, development. In the face of two powerful current reports of secretary-general of Unctad, Rubens Ricupero. IX Sessão da Conferência, 1996.

UNDP. Human development report 1996, New York. 1996. 


\section{Apêndice 1 \\ Trabalho, um valor em extinção?}

$\mathrm{Na}$ França, a transformação do trabalho em atividades autônomas tem sido uma importante questão de interesse para Jacques Robin, editor de Transversales Science/ Culture e do movimento Europa 99. Nos Estados Unidos, o livro de Rifkin (1995), com o significativo título The end of work, atraiu a atenção dos meios de comunicação. Também influenciou o pensamento de Séguin (1996). Rifkin vê a emergência de uma sociedade de duas faces: de um lado, o pequeno setor de conhecimento profissional, altamente educada, os $20 \%$ superiores da força de trabalho e, do outro, os $80 \%$ com empregos estacionários e temporários, subempregados e desempregados. Embora sua análise esteja correta, seu conceito do terceiro setor voluntário não é convincente, pois deixa de explicar como tal setor será financiado. As idéias de Rifkin são semelhantes àquelas dos proponentes franceses da économie solidaire eéconomie plurielle (Roustang, et al., 1996).

Outro conceito controverso é aquele de uma renda civil universal, isenta de imposto, difundida pela Rede Européia de Renda Básica (Basic Income European Network - BIEN) e ultimamente endossada no Reino Unido por uma comissão chefiada por lord Dahrendorf ( The Economist, 27 abr. 1996). Na França, a revista Mauss (1996) publicou um volumoso dossiê, editado por A. Caillé. Embora reconhecendo as intenções generosas dos proponentes da renda garantida, não posso aceitá-la pelas razões muito bem enunciadas por Gorz (1994): o trabalho confere cidadania econômica. Embora a abolição das esferas microssocial e privada leve à total enfeudação dos indivíduos, uma vida sem trabalho universalmente intercambiável significa que ele estará condenado à inutilidade e inexistência pública. Aznar (1996) teme que a garantia de renda leve à legitimação definitiva de uma sociedade dual. Fitoussi \& Rosanvallon (1996) assumem a mesma postura.

Em meu artigo Les temps/espaces du développement, publicado em 1980, defendi que o excedente de tempo liberado pelo trabalho heterônomo é a medida da liberdade cultural, exatamente como o excedente econômico é a medida da liberdade econômica. No tocante ao debate atual, minha posição coincide com a postura assumida por Aznar (1996:132-133): "A mutação do trabalho à qual assistimos não nos conduz ao seu desaparecimento, mas, ao contrário, à sua reinvenção. Mais que nunca parece que o trabalho constitui uma característica essencial do homem, apresentando uma característica antropológica e condicionando a expressão da identidade humana. O trabalho permite que o homem se ligue ao mundo e se ligue aos outros, instituindo um mecanismo de troca econômica, afetiva e social, ao passo que a impossibilidade de conseguir um trabalho constitui uma forma de banimento da sociedade, de uma exclusão do mundo."

Contrariamente àqueles que afirmam, como Dominique Méda (1995), que o trabalho é um valor em extinção, Aznar considera que o trabalho como valor será reinventado e conquistará novos espaços. Esta discussão filosófica não deverá desviar nossa atenção da urgência de uma abordagem mais prosaica: aumentar o investimento no setor produtivo! (De Bandt et al., 1996). Para tanto, é essencial coibir a especulação financeira. 


\section{Apêndice 2}

Uma nota sobre as estratégias de desenvolvimento geradora de empregos

1. Para evitar qualquer mal-entendido, os aumentos na produtividade da mão-de-obra são, como tais, uma gratificação: oferecem a base definitiva para o progresso econômico (mais mercadorias, menos tempo de trabalho ou uma combinação das duas coisas). O que está é jogo é: como esse progresso é administrado e partilhado? Para quem acumular as mercadorias adicionais? Quem se beneficiará da redução do tempo de trabalho e acabará sendo a vítima, excluída da força de trabalho?

2. Dadas as presentes tendências no progresso técnico, a redução do emprego não pode ser evitada nas indústrias, transformando-se em itens negociáveis e serviços modernos. Contudo, a fronteira entre os itens negociáveis e não-negociáveis não é imutavelmente fixa. Depende do grau de abertura de uma economia e da forma de sua inserção nos mercados mundiais. Além disso, através de subsídios cruzados, é possível assegurar a sobrevivência de algumas empresas familiares que exigem muita mão-de-obra e de indústrias em pequena escala.

3. A tendência rumo à substituição da mão-de-obra pelo capital é amplificada em muitos países pelos equívocos políticos de subsidiar o capital, sobretaxar os custos de mão-de-obra com os custos sociais indiretos (que poderiam ser financiados com o imposto sobre valor agregado); supervalorizar a moeda (que diminui o custo de bens de capital importados); medidas fiscais que favorecem a substituição acelerada de equipamentos (em lugar de retardar a velocidade de depreciação real).

4. A diminuição do emprego em alguns setores precisa ser compensada pela expansão de outros setores, que poderão ainda absorver a mão-de-obra, seja na forma de empregos assalariados seja por intermédio do auto-emprego, particularmente na agricultura pela lavoura camponesa familiar. A industrialização sem provocar a fuga do homem do campo (Ismail Sabri Abdallah) é provavelmente a única opção viável para países densamente povoados e uma oportunidade para os países latino-americanos e africanos, que ainda têm grandes reservas de terra para a agricultura. Os setores que desfrutam de elevados índices de aumento de produtividade da mão-de-obra deveriam ser convocados para contribuir, através de políticas fiscais apropriadas (tributando o equipamento de capital?) para financiar a expansão dos setores que absorvem a mãode-obra.

5. As considerações ambientais apontam para o objetivo de buscar maior produtividade para a energia e outros recursos naturais (aumentando o número de quilômetros por litro de combustível ou o aproveitamento de grãos por metro cúbico de água irrigada). Isso poderia ser conseguido por meio de economia de energia, água e recursos, reciclagem e reutilização do lixo e materiais, bem como ampliação, através de melhor manutenção, da vida útil das infra-estruturas, ambiente construído, equipamentos e veículos existentes. Na verdade, os critérios ambientais, econômicos e sociais muitas vezes coincidem em tais atividades trigêmeas que, muitas vezes, exigem muita mãode-obra e, no nível macroeconômico (embora não necessariamente em termos microeconômicos), se auto-financiam, pelo menos em parte, com a economia resultante de recursos, evitando ou postergando o investimento para reposição. Agendas 21 locais, urbanas ou rurais, devem estar envolvidas principalmente na identificação e implementação de tais projetos trigêmeos, para os quais o Estado deverá dar o apoio necessário na forma de linhas de crédito apropriadas, contratos de serviços e de com- 
pras, pesquisa e assistência técnica. Esta é uma área para experiências inovadoras em parcerias entre o setor público, empresas privadas, trabalhadores, cooperativas de serviços, movimentos civis e organizações. Embora o potencial de emprego das atividades descritas possa variar consideravelmente de um lugar para outro, há motivos para acreditar que ele seja considerável, principalmente por não exigir investimento adicional significativo.

6. Dado o custo proibitivo da urbanização de migrantes rurais em termos de infraestrutura, habitação e fornecimento de empregos, todas as possibilidades de um desenvolvimento rural que exija menos capital deverão ser cuidadosamente asseguradas. São elas: modernização das lavouras familiares, pela aplicação das tecnologias da segunda revolução verde fortemente científicas, poupadoras de recursos e que absorvam mão-de-obra relativas; assentamento dos trabalhadores sem-terra resultante da reforma agrária e projetos de colonização; promoção das bioenergias; industrialização descentralizada; produção de serviços para a população rural. Embora a expectativa de um bilhão de empregos em dez anos (Swaminathan) seja demasiadamente otimista, esta é de longe a reserva isolada mais importante para a criação de empregos e elemento crucial na busca de segurança em alimentos.

7. Atividades públicas permitem mais liberdade para a escolha de tecnologias apropriadas que atividades de mercado. Seu volume depende da capacidade de gerar poupança pública.

8. Em todos os países, inclusive nos industrializados, a demanda potencial de serviços sociais é bem maior que a produção atual, limitada pela falta de financiamento adequado. O progresso nesta área dependerá da capacidade de projetar sistemas menos custosos de distribuição de serviços, baseados em parcerias que envolvam o Estado, os usuários, as organizações civis (o setor privado sem fins lucrativos) e as empresas privadas. Nos países em desenvolvimento, onde são baixos os salários, atenção especial deve ser dada aos sistemas de distribuição que exijam muita mão-de-obra qualificada, cuja unidade de custo seja muito mais baixa que nos países avançados. Tal vantagem comparativa deverá levar à inversão da seqüência histórica seguida pelos países industrializados, expandindo os serviços sociais sem esperar pela riqueza. China e Cuba, mas também Sri Lanka e Kerala oferecem fortes argumentos a favor de tal abordagem.

9. Os pontos 2 a 8 desta nota formam uma lista de perguntas que fornecem um ponto de partida no processo da formulação de uma estratégia de desenvolvimento orientada para o emprego. A identificação preliminar das possibilidades de emprego deve ser aprimorada pela análise das políticas nas quais se baseiam e pela determinação dos equilíbrios macroeconômicos. O planejamento é sempre um processo iterativo. Mas o ponto de partida é importante. Por esse motivo, a prática dos registros de desemprego do país, que produziu resultados significativos nos anos 70, deveria ser revivida. 


\section{Apêndice 3}

\section{Para onde vão as economias mistas? (Leste, Oeste, Sul)}

Enquanto o neoliberalismo dogmático for um substituto ruim e perigoso para o planejamento central dogmático e o estatismo patrimonial, será necessário estimular e ajudar os países do Leste Europeu e os em desenvolvimento a pesquisar novas configurações institucionais pertencentes à ampla categoria de economias mistas.

Há, portanto, a necessidade urgente de ir além da descrição simplificada de tais economias em termos de uma justaposição de lugar de mercado e planejamento (o máximo de mercado possível, o mínimo de planejamento necessário, como diriam alguns).

A meta deveria ser a construção de uma tipologia das diversas formas de articulação existentes e plausíveis entre os setores privado, público e social (o último consistindo em cooperativas, instituições de auxílio mútuo e associações civis), bem como economia familiar que não de mercado. As diferentes formas de articulação entre os espaços local, nacional e transnacional de desenvolvimento deveriam ser igualmente consideradas (na terminologia de Streeten, 1996, os níveis macro-macro, macro, meso, micro e micro-micro).

A descrição dos cenários institucionais deveria ser complementada pela análise das formas de regulamentação das economias mistas, de alcance dos sistemas de incentivo, dos instrumentos políticos e dos caminhos de ajuste e reforma, levando do presente estado até o padrão institucional desejado.

Os caminhos de transição propostos devem ser submetidos a três critérios: eqüidade social, prudência ecológica e eficiência econômica. Tais soluções para a presente crise, capazes de minimizar os custos sociais e ecológicos, estão longe de ser evidentes e podem até exigir medidas não-intuitivas em seus estágios iniciais (por exemplo, racionamento como um meio de proteger os estratos vulneráveis da população durante a transição para um economia de mercado equilibrada). Portanto, a necessidade de análise institucional comparativa das economias mistas, conforme elas existem ou existiram nos países industrializados, nos em desenvolvimento e na Europa Ocidental durante os anos 1944-1948.

Houve considerável produção de textos sobre o tema desde a formulação desta proposta em novembro de 1989. Não obstante, ainda há espaço para uma síntese crítica comparativa. O campo de pesquisa deveria agora ser estendido para a experiência real dos países pós-socialistas e para a avaliação do impacto das reformas de liberalização nos países em desenvolvimento. 


\section{Apêndice 4}

\section{As visões do Norte e do Sul sobre a Organização das Nações Unidas*}

\section{Visão critica do Norte sobre a ONU}

A Organização das Nações Unidas precisa trabalhar em harmonia com o novo pensamento econômico e promovê-lo, dando primazia à racionalidade do mercado e encorajando a confiança no mercado como um mecanismo de tomada de decisão e de alocação de recursos em praticamente todas as esferas da vida.

Isto exige que programas obsoletos, por não corresponderem às novas abordagens atualmente preferenciais ou por serem considerados ineficientes sob o novo paradigma, sejam gradualmente desativados. Assim, espera-se que a ONU abandone seus antigos esforços para modificar o status quo econômico e abstenha-se de questionar o modo como funciona a economia mundial e seu impacto sobre o Sul.

A ONU precisa ser dinamizada e sua burocracia e custos devem ser reduzidos significativamente, levando em conta quanto seus principais contribuintes estão dispostos a pagar. É necessário permitir que os novos e poderosos atores no cenário global, como as empresas, as finanças e a mídia, tenham acesso direto e ganhem um lugar apropriado nos procedimentos da ONU.

\section{Queixas e criticas do Norte}

A ONU é demasiadamente custosa, ineficiente e difícil de administrar, tanto em relação às suas estruturas intergovernamentais e de secretariado quanto em relação aos seus procedimentos. Ela produz quantidade excessiva de documentação, tem calendário abertamente exagerado, agenda genérica e tirânica e corre o risco de se sufocar.

O princípio democrático de $u m$ Estado, um voto é irrealista, anacrônica e, por não reconhecer a hierarquia do poder, desestimula a participação séria e compromissada daqueles Estados que contam e que estão em posição de assumir responsabilidades. A aplicação do princípio de $u m$ Estado, um voto faz com que a ONU seja demasiadamente orientada pelo Sul.

O trabalho passado da Organização, especialmente no tocante à agenda do desenvolvimento Norte-Sul, mostrou-se mal orientado e deveria ser descartado. A ONU deveria limitar sua atividade inteiramente ou principalmente àquelas áreas nas quais ela tem a assim chamada vantagem comparativa, ou seja, atividades humanitárias e de manutenção da paz, desenvolvimento social e ambiente.

\section{A visão do Sul sobre a $O N U$}

A Carta Régia da ONU, a estrutura básica, o mandato e os princípios, e sua orientação para o desenvolvimento mundial são basicamente legítimos e devem ser mantidos.

A ONU como instituição deve desempenhar papel crucial como campeã da paz, da justiça e da eqüidade. Assim, um dos principais objetivos da organização, originado de sua Carta Régia, deve ser o de buscar progressos nas relações políticas e econômicas

* Fonte: For a strong and democratic United Nations: a South perspective on UN reform. Genebra, The South Centre, 1996. 
internacionais e criar um ambiente externo que contribua para o desenvolvimento dos países do Sul. Além disso, preencher a lacuna de desenvolvimento removeria uma das ameaças centrais à paz.

Internamente, a ONU deveria ser totalmente democrática e pluralista, tanto com relação aos seus procedimentos e à sua estrutura intergovernamentais quanto ao seu secretariado e pessoal. Hegemonia e privilégios especiais para aqueles capazes de exercer o poder dentro da organização não deve ter lugar na ONU pois é a própria antítese daquilo que a Organização representa.

A ONU deve ser adequadamente financiada para realizar as várias tarefas correspondentes aos objetivos e à agenda decididos pelos governos-membros. Deve ter um quadro pessoal adequado, constituído por pessoas selecionadas por sua excelência e motivação e que possam trabalhar juntas num espírito verdadeiramente internacional com a finalidade de atingir as metas determinadas através de um acordo internacional, livres das pressões exercidas por Estados poderosos.

\section{Os desafios enfrentados pela ONU: a visão do Sul}

A Carta Régia da ONU e seus princípios mais importantes sofreram corrosão e correm perigo. O poder econômico e político do Norte é utilizado mais abertamente que nunca para minar o caráter democrático e pluralista da Organização.

A ONU tem orçamento e quadro pessoal insuficientes em áreas-chave de seu trabalho, que correspondem aos diversos mandatos e objetivos ambiciosos determinados pela Organização. De fato, não lhe é permitido exercer seus mandatos integralmente, nem lhe são fornecidos os meios institucionais para implementar sua agenda de maneira sistemática. A ONU é portanto sobrecarregada com problemas e expectativas que dão origem a acusações de incompetência e ineficiência.

A estrutura intergovernamental e o secretariado da ONU estão sob pressão cada vez maior, exercida por alguns países poderosos do Norte, que tencionam dominar a Organização com o objetivo de determinar unilateralmente a sua agenda e os seus desfechos políticos.

O papel criticamente importante da Organização no campo do desenvolvimento econômico está sendo denegrido pelo Norte, que gostaria de impedir a ONU de atuar como um crítico e um agente de mudança face a face com o sistema global dominado pelo Norte. A meta do Norte é privar a ONU de suas capacidades política e de pesquisa na esfera econômica e dar a ela um papel mais central no campo econômico e de desenvolvimento às instituições de Bretton Woods e à $\mathrm{OMC}$ - instituições que são dominadas pelo Norte, não-democráticas e diferem na inspiração basicamente política da ONU.

A ONU é efetivamente impedida de adotar uma abordagem integrada e coordenada para os problemas globais e suas causas primárias, o que se deve em parte ao fato de ela ser impedida de ter qualquer jurisdição ou influência sobre aquelas áreas de política econômica e social, entre outras, dos países industrializados do Norte, cujo impacto seja global.

A incapacidade da Organização de estimular a implementação de políticas de desenvolvimento mais apropriadas e voltadas para o povo, no Sul, resultou em exemplos cada vez mais numerosos de desenvolvimento fracassado, dando origem a graves crises que acabam por exigir que a ONU dedique esforços e recursos substanciais para as atividades humanitárias e de manutenção da paz. 
A ONU está sendo transformada num instrumento de interferência direta ou indireta na governança dos voláteis e instáveis países em desenvolvimento, levantando questões não somente sobre a pertinência e adequação das medidas adotadas, mas também sobre a responsabilidade na tomada de decisões sobre esses temas.

Ignacy Sachs é professor da École des Hautes Études en Sciences Sociales, em Paris, França.

Texto apresentado pelo autor no seminário Condições para o progresso social: uma economia mundial para o benefício de todos, realizado de 4 a 6 de outubro de 1996, em Havreholm Castle, Copenhague, Dinamarca.

Tradução de Vera de Paula Assis. O original em inglês - Developing in a liberalized and globalizing word economy: an impossible challenge? - encontra-se à disposição do leitor no IEA-USP para eventual consulta. 